\title{
Spores in a Specimen of Tempskya (Endogenites).
}

\author{
BV \\ L. A. BOODLE, A.R.C.S. \\ Demonstrator in Botany at the Royal College of Science, London.
}

GPECIMENS of the Wealden fossil known as Tempsky $c$ $S$ Schimperi, Cord., or Endogenites erosa, Mant., have often very little of their original structure preserved, sometimes - a great deal. A striking difference in this respect is shown by sections of some specimens, which I collected near Brightstone (in the Isle of Wight), and at Hastings respectively. Those from the first locality contain numbers of vascular bundles, whose tracheides have their scalariform thickenings perfectly preserved. In those from the second locality the outlines of the roots are distinguishable, but the xylem has entirely disappeared in nearly all cases.

One of these latter specimens, in spite of the general obliteration of structure, contains a group of spores in remarkably good preservation. As spores do not appear to have been seen before in Tempskya, it may be worth while to describe them.

A. C. Seward ${ }^{1}$ has quite recently published a description of Tempskya, with a summary of previous work. It will,

${ }^{1}$ Seward, Catalogue of Mesozoic Plants in Dep. Geol. Brit. Mus. The Wealden Flora, Part I, I 894 (p. I48).

[Annals of Botany, Vo1. IX. No. XXXIII. MIarch, 1895. 


\section{I38 Boodle.-Spores in a Specimen of}

therefore, only be necessary to mention the general structure shortly, before describing the spores.

The following is the diagnosis as given by Seward ${ }^{1}$ :-

'Masses of numerous branched adventitious roots, and a few small ? petioles forming masses, occasionally several

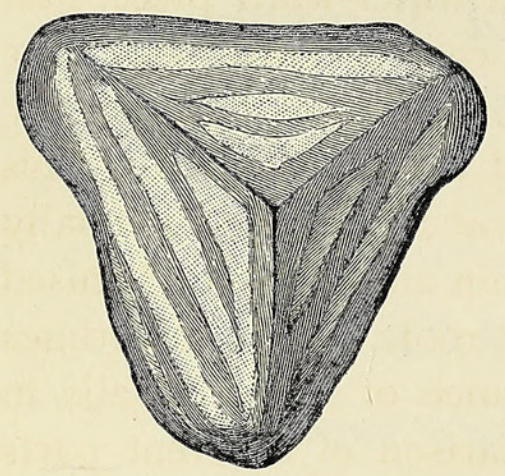

Fig. I.

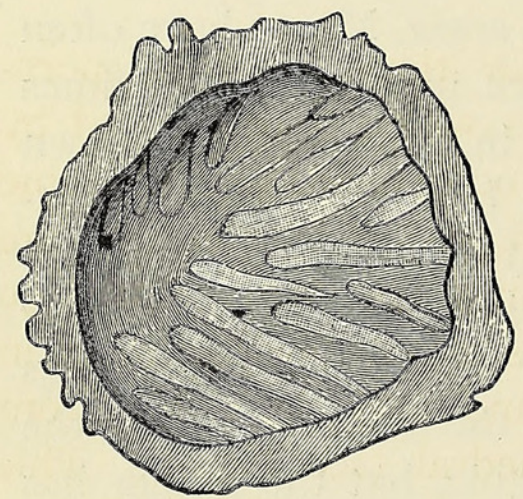

Fig. 3.

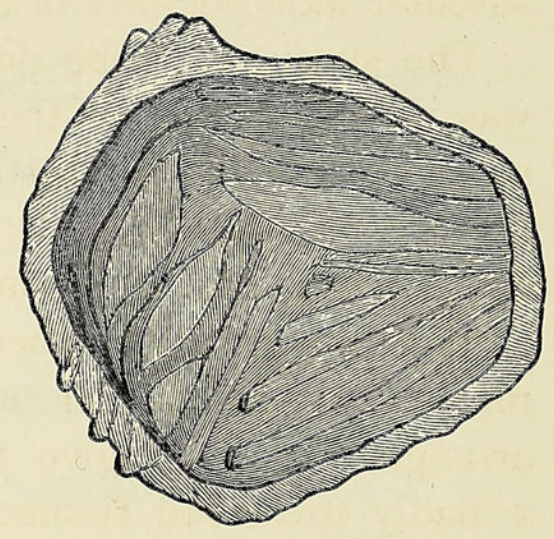

Fig. 2.

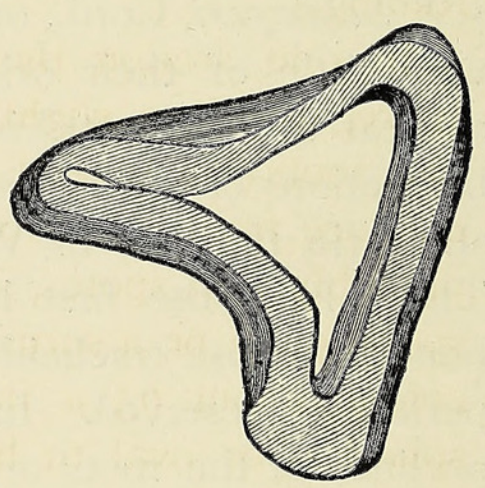

Fig. 4 .

Woodcut I.

Fig. I. Exterior of spore, showing the angle upwards. Fig. 2. Spore cut in half, interior view. Fig. 3. Spore similarly cut, but with different markings. Fig. 4. Collapsed spore in section. The figures are slightly diagrammatic, and the spores are drawn as opaque objects, for simplicity. Where the wall of a spore is shown in surface-view, the light areas represent the pits, the darker parts are the thickenings. Figs. all $\times 545$.

feet in length, and in large specimens about one foot in diameter; the transverse section of the mass is often elliptical in shape, no doubt as the result of pressure; the ends of

\footnotetext{
1 Loc. cit., p. I5I.
} 
the specimens frequently taper to a pointed termination, and the external surface may be covered over with a layer of coaly substance representing carbonised tissue. The roots are of the diarch type, and the petiole structures are characterized by a horseshoe-shaped vascular band. (The central vascular axis possibly of the Protopteris form.)'

The specimen to be described is a water-worn piece, that was picked up below the cliffs just east of Hastings. The vascular bundles of the roots have nearly all disappeared, and their place is mostly represented by a clear area. This consists of quartz ${ }^{1}$ surrounding a central cavity, or occasionally without any cavity. There is a certain amount of carbonised material in the cortical region of the roots. It is sometimes arranged so as to give the appearance of the cell-walls in a badly preserved tissue; but comparison of different parts of the section proves that this appearance is often misleading.

In one section there are two or three hundred spores aggregated in a slightly lobed mass which is penetrated by two roots (?); several spores also occur scattered at some distance from it. From their form and structure they are probably fern spores, and their arrangement suggests a large sporangium or a sorus. The spores are yellowish brown in colour, about $65 \mu$ in diameter, and vary in shape from spherical or oval to bluntly tetrahedral (see Figs.). This apparent variation is, of course, partly due to the varying positions of the spores. A considerable number of the spores must have been shrunk before the specimen was mineralised; thus causing irregularities of form, such as Fig. 4 exhibits, where the spore is shown in section. The wall of the spore is in nearly all cases strongly pitted, and the thickenings take the form of bars, which run roughly parallel with one another, and fuse at intervals. There is a good deal of variation in the form of the thickenings, but Fig. I may be taken as a typical appearance of the spore when viewed from the

1 Dr. W. F. Hume has kindly examined a slide and determined that this is secondary quartz, formed in the cavities by subsequent infiltration. 
angular side. Figs. 2 and 3 represent internal views of spores in other positions. In some cases the pits and bars run uniformly, and all parallel, right across the spore. One spore is apparently not mature, having a smooth wall. There seems little doubt that the structures described above are spores, but it is as well to regard other possibilities. A group of short detached tracheides, such as one sees in the central region of the old stem of Isoëtes, would present an appearance somewhat like that of the spore-mass in question, but the frequency of tetrahedral form is strongly in favour of their being spores, as is also the fact of their being so well preserved in a specimen from which the xylem has disappeared. For, if they were tracheides, they would doubtless be lignified, and as liable to be destroyed as the xylem of the roots; but spores, when strongly cuticularised, would be much more resistent to decay.

Surrounding the group of spores there is a layer consisting of carbonaceous matter in the form of small cylindrical rods placed end to end, and running peripherally. These differ from the carbon masses in other parts of the section, and may possibly represent casts of cells belonging to an indusium, a sporangium-wall, or a tuft of hairs.

Mr. Carruthers kindly pointed out to me the spores of Trochopteris elegans ${ }^{1}$, as most nearly resembling those described above, among living ferns. The thickenings in the spore-wall are very similar in the two cases. The spores are almost exactly of the same shape, and of the same average size, individual spores varying considerably. Though many spores of Trochopteris have their thickenings slightly differently arranged, e.g. more uniformly parallel, twisted at the angles of the spore, or more closely set, still certain spores have their pits and thickenings almost precisely as in Tempskya; thus one spore examined was a nearly exact counterpart of that shown in Fig. I.

1 Through the kindness of Mr. Carruthers I was enabled to examine the spores of Trochopteris, Ceratopteris, and other genera in the Herbarium of the British Museum. 
This close resemblance in the spores need not, however, point to any near affinity with Trochopteris, which belongs to the Schizaeaceae. The spores of Ceratopteris thalictroides among the Polypodiaceae or Parkeriaceae have thickenings of a similar but not identical type with Trochopteris. Thus, though this type of spore-thickening is uncommon, it occurs in plants that do not seem to be nearly related to one another; and therefore the resemblance to Trochopteris in spore-structure is insufficient, without the evidence of any sporangial structure, for referring the fossil spores to the neighbourhood of the Schizaeaceae.

The spores of Dicksonia, which has been compared with Tempskya, are nearly smooth, with occasional warts or slight ridges.

There is no evidence that the spores in Tempskya belong to the same plant as the adjacent roots. Should any spores be found in a specimen containing xylem, it is to be hoped that the sporangium would be preserved, and that the attachment to a leaf stalk might be determined. I am indebted to Prof. Judd, Prof. Farmer, and Mr. Seward for assisting me with suggestions. 


\section{$2 \mathrm{BHL}$ Biodiversity Heritage Library}

Boodle, Leonard Alfred. 1895. "Spores in a specimen of Tempskya (endogenites)." Annals of botany 9, 137-141. https://doi.org/10.1093/oxfordjournals.aob.a090726.

View This Item Online: https://www.biodiversitylibrary.org/item/233478

DOI: https://doi.org/10.1093/oxfordjournals.aob.a090726

Permalink: https://www.biodiversitylibrary.org/partpdf/318369

\section{Holding Institution}

Smithsonian Libraries

\section{Sponsored by}

Biodiversity Heritage Library

\section{Copyright \& Reuse}

Copyright Status: Not in copyright. The BHL knows of no copyright restrictions on this item.

This document was created from content at the Biodiversity Heritage Library, the world's largest open access digital library for biodiversity literature and archives. Visit BHL at https://www.biodiversitylibrary.org. 